\title{
Functional reorganization of marine fish nurseries under climate warming
}

\author{
McLean Matthew J. ${ }^{1,2,{ }^{*} \text {, Mouillot David }}{ }^{2,3}$, Goascoz Nicolas ${ }^{4}$, Schlaich Ivan ${ }^{4}$, Auber Arnaud ${ }^{1}$
}

1 IFREMER, Unité Halieutique de Manche et mer du Nord; Boulogne-sur-Mer ,France

${ }^{2}$ MARBEC, Université de Montpellier, CNRS, IFREMER, IRD; Montpellier Cedex, France

${ }^{3}$ Australian Research Council Centre of Excellence for Coral Reef Studies; James Cook University; Townsville Queensland, Australia

${ }^{4}$ IFREMER; Laboratoire Ressources Halieutiques; Port-en-Bessin ,France

*Corresponding author : Matthew J.McLean, email address : mcleami@gmail.com

\begin{abstract}
:
While climate change is rapidly impacting marine species and ecosystems worldwide, the effects of climate warming on coastal fish nurseries have received little attention despite nurseries' fundamental roles in recruitment and population replenishment. Here, we used a 26-year time series (1987-2012) of fish monitoring in the Bay of Somme, a nursery in the Eastern English Channel (EEC), to examine the impacts of environmental and human drivers on the spatial and temporal dynamics of fish functional structure during a warming phase of the Atlantic Multidecadal Oscillation (AMO). We found that the nursery was initially dominated by fishes with r-selected life-history traits such as low trophic level, low age and size at maturity, and small offspring, which are highly sensitive to warming. The AMO, likely superimposed on climate change, induced rapid warming in the late 1990 s (over $1^{\circ} \mathrm{C}$ from 1998 to 2003), leading to functional reorganization of fish communities, with a roughly $80 \%$ decline in overall fish abundance and increased dominance by K-selected fishes. Additionally, historical overfishing likely rendered the bay more vulnerable to climatic changes due to increased dominance by fishing-tolerant, yet climatically sensitive species. The drop in fish abundance not only altered fish functional structure within the Bay of Somme, but the EEC was likely impacted, as the EEC has been unable to recover from a regime shift in the late 1990s potentially, in part, due to failed replenishment from the bay. Given the collapse of r-selected fishes, we discuss how the combination of climate cycles and global warming could threaten marine fish nurseries worldwide, as nurseries are often dominated by r-selected species.
\end{abstract}

Keywords : Atlantic Multidecadal Oscillation, climate change, ecosystem function, English Channel, fisheries, functional traits, life history, recruitment 


\section{Introduction}

Climate change impacts are increasingly prevalent in marine ecosystems worldwide, with documented shifts in species' distributions and community composition driven by increasing temperatures, reduced oxygen, and ocean acidification (Shaffer et al., 2009; Sunday et al., 2016; Givan, Edelist, Sonin, \& Belmaker, 2018; Nash et al., 2017). Such climate change impacts are further expected to increase in frequency and severity under current projections of carbon dioxide emissions and ongoing warming (Comte \& Olden, 2017; Henson et al., 2017). However, as recent climate change has been exceptionally rapid (Bradshaw \& Holzapfel, 2006; Loarie et al., 2009; Schofield et al., 2010; Burrows et al., 2011) with more frequent extreme events (Diffenbaugh et al., 2017; Frölicher, Fischer, \& Gruber, 2018; Hughes et al., 2018), scientists are only beginning to understand the many different ways global warming can impact ecosystems and communities, and latent impacts have likely gone undocumented.

As most studies have examined the impacts of climate warming on ecological communities through species-based approaches (Poloczanska et al., 2013; Wiens, 2016), it remains relatively unknown how increasing temperatures might alter communities' functional structures (i.e., the composition of species' functional traits) (Frainer et al., 2017). Functional-trait approaches are particularly valuable for understanding climate change impacts as environmental change affects organisms through their functional characteristics (e.g., diet, habitat preference, life-history), which have known links to ecosystem processes (Buisson et al., 2013; Gallagher et al., 2013; Villéger et al., 2017). Understanding how ecosystem functioning could change under future warming is critical to maintaining ecosystem services, and therefore studies assessing the functional responses of fish communities to climate change are urgently needed.

This article is protected by copyright. All rights reserved. 
Marine fish nurseries are critical habitats for maintaining ecosystem diversity and productivity because they act as population sources for larger ecosystems via recruitment and replenishment (Beck et al., 2001; Gillanders et al., 2003; Dahlgren et al., 2006; Vasconcelos et al., 2010). For example, mangrove and lagoon nurseries make substantial contributions to adult populations in nearby ecosystems, as they provide productive structural habitats suitable for rapid growth and maturation (Nagelkerken et al., 2017; Tournois et al., 2017). Thus, changes in fish nurseries could have major impacts in larger, adjacent ecosystems. Furthermore, nurseries could be particularly sensitive to climate warming as they are depthlimited and likely to warm quickly with limited inertia to temperature fluctuations (Dulvy et al., 2008; Rutterford et al., 2015). However, the impacts of climate warming on fish functional structure and ecosystem functioning in marine nurseries have been surprisingly understudied, and few studies have disentangled the impacts of climatic and human pressures in such ecosystems. (Nicolas, Lobry, Le Pape, \& Boët, 2010 ; Petitgas et al., 2013; Chevillot et al., 2016; Sloterdijk et al., 2017).

In the present study, we assessed the influences of environmental drivers and fishing on the spatial and temporal dynamics of fish functional structure in the Bay of Somme, an estuary in northwestern France that provides a nursery habitat for the Eastern English Channel. By examining communities in the Bay of Somme through a functional-trait approach, we found that the nursery was inherently susceptible to climate warming, as communities were initially dominated by fishes with environmentally-sensitive life-history traits. Consequently, fish functional structure changed significantly over time in parallel to exceptional sea surface warming, which was likely exacerbated by historical overfishing. Our study fills a critical knowledge gap by highlighting how climate warming can impact fish nurseries over long time periods, providing valuable information for fisheries management and conservation planning. 


\section{Materials and Methods}

\section{Study site and fish community sampling}

The Bay of Somme is an estuary of the Eastern English Channel (EEC), which provides a nursery for several commercially-important marine fish species such as plaice, sole, and herring (Rybarczyk et al., 2003; Le Pape, 2005; Auber et al., 2017). The Bay of Somme is the second largest (of five) major fish nurseries in the EEC and is representative of regional estuary habitats (Le Pape, 2005). The bay forms the mouth of the Somme River, but is primarily a marine ecosystem with an estuary habitat limited to the river channel (Rybarczyk et al., 2003; Auber et al., 2017). The bay has an intertidal surface of more than $50 \mathrm{~km}^{2}$ with a maximal tidal range of $11 \mathrm{~m}$ and an average tidal volume of $200 \times 10^{6} \mathrm{~m}^{3}$ (Rybarczyk et al., 2003). The main river input comes from the Somme River, which has an estimated average runoff of $33.6 \mathrm{~m}^{3} \mathrm{~s}^{-1}$ (Rybarczyk et al., 2003). Fish communities in the bay have been surveyed in late summer each year since 1987 during the NOURSOM fish monitoring campaign, and data from 1987 to 2012 were included in this study. Fish survey methods were defined according to three depth zones: inner bay from the shoreline to the mouth of the bay, $0-5 \mathrm{~m}$ deep in the outer bay, and $0-11 \mathrm{~m}$ deep in the outer bay (Figure 1). The monitoring campaign aimed to complete 44 hauls each year (based on feasibility): 16 hauls in the inner bay using a beam trawl with a 2-m horizontal opening (CP2), and 28 hauls in each zone of the outer bay using a beam trawl with a 3-m horizontal opening (CP3). The vertical opening was $0.31 \mathrm{~m}$ for $\mathrm{CP} 2$ trawls and $0.42 \mathrm{~m}$ for $\mathrm{CP} 3$ trawls, while the stretched mesh size was 20 $\mathrm{mm}$ for both. All CP2 hauls lasted 7 minutes while CP3 hauls lasted 15 minutes. Trawls were conducted during daylight hours at an average speed of 2.5 knots. Within each haul, fishes were identified and counted and all abundance values were standardized to numbers of individuals per $\mathrm{km}^{2}$. 


\section{Environmental factors}

We examined both local environmental factors as well as Atlantic-wide climate oscillations known to alter environmental conditions across multiple spatial scales (Dickson, 2000; Edwards et al., 2013). Local environmental factors included depth, sea surface temperature (SST), salinity, chlorophyll-a, suspended sediment, and bed shear stress (i.e., water velocity along the bottom), all of which have well-documented influences on the structure and distribution of marine fish communities (Bœuf \& Payan, 2001; Beaugrand, 2004; Hermant, Lobry, Bonhommeau, Poulard, \& Le Pape, 2010; Kjelland et al., 2015). Depth and salinity were measured in-situ during the NOURSOM survey. Spatially-resolved data for SST, chlorophyll-a and suspended sediment were derived from satellite data for the period $1998-$ 2012 (Gohin, 2011) and bed shear stress was taken from a 3D hydrodynamic model developed by Aldridge \& Davies (1993). These data were used for spatial analyses only. For temporal analyses, mean-annual SST for the entire bay was derived as the average of all sources available for the entire time series. These included the HadISST database (Rayner et al., 2003), the kriging-interpolated Ifremer AVHRR/Pathfinder database (Saulquin \& Gohin, 2010), in-situ measurements recorded during the ecological monitoring campaign of the Penly Nuclear Power Plant (NPP; mean of April, July, and September) (Cochard, 2002), and in-situ measurements taken during Ifremer plankton monitoring campaigns (mean of May and June) (Ifremer unpublished data). Mean-annual salinity was derived as the average of insitu measurements taken during the Penly NPP and Ifremer plankton monitoring campaigns. Both mean-annual chlorophyll-a and suspended sediment were measured in-situ during the Penly NPP environmental monitoring campaign (Cochard, 2002).

The North Atlantic Oscillation (NAO) and Atlantic Multidecadal Oscillation (AMO) are naturally-occurring, basin-wide climate oscillations that influence sea surface temperatures and oceanographic processes across the North Atlantic Ocean (Dickson, 2000;

This article is protected by copyright. All rights reserved. 
Edwards et al., 2013). Specifically, the NAO is an alteration of atmospheric mass over the North Atlantic, which is characterized by warm, wet conditions during positive phases and cold, dry conditions during negative phases (Dickson, 2000; Hurrell et al., 2003), while the AMO is a 60 - 80-year cycle of North Atlantic sea surface temperatures (Enfield et al., 2001). Such basin-wide climate oscillations have been shown to impact ecosystem processes and biodiversity at local spatial scales, including estuaries (Hallett et al., 2004; Tolan, 2007). Annual values of both the NAO and AMO (unsmoothed) came from the National Oceanographic and Atmospheric Administration (NOAA, US).

\section{Fishing pressure}

The Bay of Somme has no local commercial fishery (outside of a small shrimp harvest), and there have been nearly no commercial landings in the bay in the last 40 years (Dreves et al. 2010). Although there is no local fishery, as the bay provides a nursery for the EEC, fishing in the EEC has a potential impact on fish communities in the bay. Fishing pressure indices at the community and gear-type level were unavailable for the EEC prior to 2000. While fishing mortality indices are available, they are limited to few quantitatively-assessed commercial species. However, long-term fisheries landings data in the EEC were available for 34 (of 52; see fish functional structure below) Bay of Somme taxa for 1987 - 2010. Annual fisheries landings (tons per year) for each species for the entire EEC (International Council for Exploitation of the Sea [ICES] area VIId) were therefore extracted from the ICES catch statistics database (ICES).

This article is protected by copyright. All rights reserved. 


\section{Fish functional structure}

We characterized fish functional structure using nine traits related to life history, habitat use, and trophic ecology (Table 1). Functional trait data came primarily from FishBase (Froese \& Pauly, 2012), Engelhard et al., (2011), and Pecuchet et al., (2017). A literature search was also conducted to find missing trait values not available in the above sources. We compiled functional trait data for all observed species and taxonomic groups for which data were available, resulting in 52 taxa (48 species, 4 identified to genus level only; Appendix 1). The final trait database had only 5 missing values out of 468 possible (9 traits $x 52$ taxa) (Appendix 1). Temperature preference was calculated as the median sea surface temperature of a species' occurrences across its global range of observations for which data were available. Occurrence data came from FishBase, the Global Biodiversity Information Facility https://www.gbif.org/, and the Ocean Biogeographic Information System http://iobis.org/.

We first generated a table of community-weighted mean (CWM) trait values using $\log _{10}(\mathrm{x}+1)$ transformed abundances and standardized traits for all sampling locations and years for the entire Bay of Somme. We then ran preliminary analyses to determine the relative importance of spatial and temporal dynamics in explaining overall variation in fish functional structure. For these preliminary analyses, we aggregated sampling locations to fifteen spatial sites by rounding the latitude and longitude of each sampling location to the nearest tenth of a degree, which created an evenly-spaced spatial grid. Aggregating sampling locations to evenly-spaced sites was necessary to examine spatial variation as sampling locations were never re-sampled, and each sampling location corresponded to one row in the dataset. To determine the relative importance of space and time we used redundancy analyses (RDA) with i) aggregated spatial sites and ii) years as single explanatory factors. RDA is a method for examining the variation in a set of response variables (i.e., fish communities) using a set of explanatory variables, and is conceptually synonymous to multivariate 
regression (Borcard et al., 2011). The initial RDA analyses revealed that spatial dynamics explained $26.3 \%$ of overall variation, while temporal dynamics explained $5.6 \%$, indicating strong spatial heterogeneity masking temporal changes. We therefore first examined spatial fish functional structure to determine how functional groups were distributed across the bay. Spatial functional structure was examined by applying K-means clustering to the entire CWM trait table with all sampling locations across all years (the R-package nbclust was used to determine the optimal number of clusters) and SIMPER analysis was used to characterize differences between the resulting clusters. K-means clustering is a least squares partitioning method for finding data groupings, while SIMPER assesses the contribution of individual variables to the dissimilarity between groups (Clarke, 1993; Borcard et al., 2011). Initial analyses revealed strong spatial differentiation between two clusters corresponding to innerbay and outer-bay communities (Figure 1; Figure S1) and we therefore proceeded by examining fish functional structure in each cluster individually, to examine temporal dynamics without the overwhelming effect of spatial heterogeneity.

To further characterize overall fish functional structure, we also built a multidimensional functional-trait space, where species are arranged according to their functional relatedness (Mouillot et al., 2013). The functional space was created by applying principal coordinates analysis (PCoA) to a Gower dissimilarity matrix of the species by functional trait table for the entire Bay of Somme, and was primarily examined using the first two principal coordinate axes, which cumulatively explained $54 \%$ of the total variance. PCoA is an ordination method for examining similarity among objects by transforming a dissimilarity matrix into a multidimensional space (Borcard et al., 2011). Building a functional space allows visualizing overall functional structure, determining whether changes in functional structure are driven by few or several species, and identifying similarities 
among impacted species. Functional space was built with PCoA as this ordination method is compatible with Gower's distance, which can integrate multiple types of traits.

Temporal functional dynamics were examined by applying principal component analysis (PCA) to an annual CWM trait table for each cluster. PCA is an ordination method used to visualize the structure of a dataset and identify similarities or patterns among objects (Borcard et al., 2011). In contrast to PCoA, PCA uses similarity matrices (e.g., Euclidean) with continuous data. Significant changes in temporal functional structure were assessed by testing for changes in the first and second PCA axes using linear regressions. PCA loadings (functional traits most associated with PCA axes) were then examined to determine which functional traits best explained temporal variation, and the dynamics of each trait were tested using linear regressions to identify which traits significantly increased or decreased in relative abundance through time. We further examined temporal changes in functional structure by examining changes in species' abundances in the functional space and by calculating annual abundance-weighted community centroids.

\section{Influences of environmental factors on spatial fish functional structure}

We tested the influences of environmental factors in driving spatial variation in fish functional structure between clusters using a partial redundancy analysis (pRDA) designed to control for and remove the influence of temporal variation. pRDA is a constrained RDA that removes the effect of one or more explanatory variables prior to analysis (Borcard et al., 2011). Spatially-resolved data were unavailable prior to 1998 , and thus spatial environmental variables represent the spatial regime for the time period 1998 - 2012. However, preliminary analyses showed that spatial differences between clusters were maintained throughout the entire time series (Figure S1), indicating consistent spatial variation in environmental drivers. 
Spatial variables included depth, SST, salinity, chlorophyll-a, suspended sediment, and bed shear stress. Significance of the pRDA was tested using Monte-Carlo permutation tests and the most parsimonious models were identified using forward selection according to Variance Inflation Factors (VIF), F-statistics, and P-values (Borcard et al., 2011).

\section{Influences of environmental factors on temporal fish functional structure}

Spatially-resolved environmental data were unavailable prior to 1998; however, mean-annual environmental data for the entire Bay of Somme were available for the overall time series. We therefore examined temporal relationships between environmental variables and fish functional structure in each overall cluster. We tested relationships between environmental variables (AMO, NAO, SST, salinity, chlorophyll-a, and suspended sediment) and the first principal component (PCA axis 1) of temporal fish functional structure in each cluster using cross correlations of three-year moving averages (Figure 3b, c). Cross correlation identifies significant correlations in time series while accounting for potential time lags between variables, and thus can i) identify apparent cause-effect relationships because a causal variable must come before an effect variable in temporal sequence, and ii) identify drivers with time-lagged ecological effects. Moving averages were used to reduce stochastic variation and highlight long-term tendencies. Cross correlations were first ran using standard inference testing $\left(r_{\text {critical }}\right.$ with d.f. $\left.=\mathrm{N}-2\right)$, and secondly re-run with modified $r_{\text {critical }}$ values to account for temporal autocorrelation, using the correlogram product method of Clifford, Richardson, \& Hemon (1989), where the standard deviation of the correlation between two processes is calculated as the square root of the weighted product of their autocorrelation functions (ACFs). This increases the correlation coefficient required to achieve significance 
$\left(r_{\text {critical }}\right)$, as temporal autocorrelation can inflate Type-I error due to lowered degrees of freedom.

\section{Influences of fisheries landings on temporal fish functional structure}

As we were unable to examine the impact of fishing pressure in the EEC on fish functional structure in the Bay of Somme at the community level, we examined the relationship between fisheries landings and abundance for each species individually (34 with available data). Thus we were able to determine whether changes in the abundance of each species in the bay were likely driven by fishing in the EEC. We examined landings for each species individually rather than compiling landings for the entire EEC community, as few dominant species comprise the majority of overall landings. We tested relationships between changes in the abundance of individual species and their corresponding landings within each cluster using linear regression models. Abundance data were $\log _{10}(x+1)$ transformed before analyses.

\section{Results}

\section{Spatial fish functional structure}

We found two distinct spatial functional clusters corresponding to inner and outer-bay communities (Figure 1). Fish communities in the inner bay were mainly characterized by benthopelagic planktivores and piscivores, while fish communities in the outer bay were characterized by demersal benthivores (SIMPER analysis, top 50\% of cumulative variation). Functional space revealed that while inner and outer-bay communities were primarily characterized by differences in habitat preference and trophic guild, communities in both 
zones were dominated by fishes with low trophic level, low size and age at maturity, and small offspring (Figure 2a-c).

\section{Temporal changes in fish functional structure}

Fish functional structure changed significantly over time in both inner and outer-bay communities, as we found significant changes in PCA axis 1 in both clusters (inner: $F_{1,24}=$ 26.68, $p<0.0001$; Figure 3c; outer: $F_{1,24}=23.02, p<0.0001$; Figure 3d). Examination of PCA loadings revealed that temporal dynamics in inner-bay communities were mainly explained by relative decreases of planktivores and increases in fecundity and trophic level (Figure 3a). Temporal variation in outer-bay communities was explained by relative increases in age at maturity and trophic level, decreases in benthivores and increases in piscivores (Figure 3b). Using regression analysis, we further found that relative length and age at maturity and fecundity significantly increased in both inner and outer-bay communities, which was accompanied by a relative increase in benthopiscivores and piscivores (Table 2). In outer-bay communities there was also an increase in trophic level and temperature preference (Table 2). By contrast, planktivores decreased in inner-bay communities, while benthivores decreased in outer-bay communities (Table 2). Parental care also decreased in inner-bay communities (Table 2).

The first axis of functional space (PCoA axis 1) was primarily characterized by differences in water-column position, while the second axis (PCoA axis 2) corresponded to differences in trophic level, length and age at maturity, offspring size, and trophic guild (Figure 2a-c). Consequently, there was little temporal change in community centroid movement along the first axis of functional space, which corresponded more to spatial differences between clusters. However there was a major change in the second axis (PCoA 
axis 2) as species that strongly declined in abundance were located in the upper half of the functional space, corresponding to low trophic level, early maturation, and small reproductive size (Figure 2d-f). Further examination of functional space revealed that overall temporal changes in fish functional structure were driven by decreasing abundances of the most dominant species, rather than increases in subordinate species (Figure 2e, f). Thus, temporal dynamics were characterized primarily by decreases in two functional groups - demersal benthivores and benthopelagic planktivores - with r-selected life history traits, which lead to relative increases in length and age at maturity, fecundity and trophic level over time. Furthermore, we found that there was a roughly $80 \%$ decrease in overall fish abundance in the bay throughout the time series, highlighting that the long-term dynamic of fish communities in the Bay of Somme was a considerable decrease in abundance.

\section{Drivers of spatial and temporal dynamics}

Spatial differences in fish functional structure between inner and outer-bay clusters were primarily driven by strong gradients in depth and bed shear stress, as the most parsimonious model included only these two variables (pRDA; $F_{2,46}=51.7, p<0.001$; Figure 4 Figure S2). Inner-bay sites were characterized by shallow depth and high bed shear stress associated with estuary discharge, while outer-bay sites were deeper with lower bed stress. Salinity was also associated with differences between spatial zones, as the inner-bay had lower salinity due to freshwater input; however, given strong covariation with both depth and bed stress, salinity was not retained in the most parsimonious model.

Initial cross correlation analyses with standard inference tests revealed that temporal changes in fish functional structure were strongly associated with changes in AMO and SST. AMO was correlated with PCA axis 1 in the inner-bay for all time lags from 0 to 7 years 
(max correlation: $r=0.66, p<0.001$; Figure 3c), and with PCA axis 1 in the outer-bay for lags 0 to 6 years (max correlation: $r=0.64, p<0.001$; Figure $3 \mathrm{~d}$ ). SST was correlated to inner-bay PCA axis 1 for time lags 2 to 8 years (max correlation: $r=0.65, p<0.001$; Figure 3c), and outer-bay PCA axis 1 for time lags 0 to 6 years (max correlation: $r=0.78, p<0.001$; Figure 3d). NAO was also correlated to both inner and outer-bay PCA 1 axes; however, these correlations were for negative time lags, indicating changes in fish functional structure precluded a decrease in NAO. None of the other variables (salinity, chlorophyll-a, or suspended sediment) were correlated with PCA axis 1 in either cluster. Re-running analyses with increased $r_{\text {critical }}$ values to account for temporal autocorrelation showed that AMO remained correlated with PCA axis 1 in the inner-bay for time lags 3 and 4 years, while SST was correlated to inner-bay PCA axis 1 for time lags 3 to 7 years and outer-bay PCA axis 1 for time lags 1 to 3 years. Thus, despite high temporal autocorrelation in the data, typical of ecological and environmental time series, associations between temporal changes in fish functional structure and warming remained significant even with $r_{\text {critical }}$ values inflated by 40$73 \%$.

In the inner bay, fish abundances were significantly related to fisheries landings for only one species, Phycis blennoides, however this relationship was positive, indicating that abundances and landings increased simultaneously $\left(F_{1,22}=12.1, p<0.01\right.$; Appendix 4$)$. In the outer bay, abundances were significantly related to landings for only three species, Limanda limanda, Pleuronectes platessa, and Dicentrarchus labrax, however these relationships were again all positive, indicating that that landings did not drive changes in abundances (Limanda limanda: $F_{1,22}=11.74, p<0.01$; Pleuronectes platessa: $F_{1,22}=7.15, p$ $<0.05$; Dicentrarchus labrax: $F_{1,22}=4.4, p<0.05$; Appendix 4). The relationship between fisheries landings and abundance was non-significant for all other taxa in both the inner and outer bay (Appendix 4). To further account for potential time lags, we also examined cross 
correlations between landings and species' abundances for lags $1-5$ years, and of 115 possible correlations in the inner bay ( 23 species x 5 lags), only two were negative and significant (Trisopterus luscus, 4-year-lag; Merlangius merlangus, 4-year-lag), and of 155 possible in the outer bay (31 species x 5 lags) only 1 was negative and significant (Scophthalmus maximus, 5-year-lag). Although both Trisopterus luscus and Merlangius merlangus decreased in the inner bay, they did not contribute substantially to overall change (i.e., not within top 20\%ile), however Scophthalmus maximus had one of the largest increases in the outer bay (Appendix 3).

\section{Discussion}

We found that fish communities in the Bay of Somme underwent substantial changes in functional structure characterized by a switch from r-selected to K-selected dominance. This functional switch, between fast and slow life histories, was associated with increasing sea surface temperatures linked to a warming phase of the AMO. The AMO switched from a cool to warm phase in the late 1990s, and such natural climate oscillations superimposed on manmade climate change can lead to accelerations in ocean warming (Ting et al., 2009; Cai et al., 2014; Moore et al., 2017). Therefore it appears the AMO interacted with long-term global warming, driving increases in SST in the Bay of Somme, which likely caused the pronounced changes in fish functional structure found here.

We found strong spatial structuring in the Bay of Somme driven by a gradient of depth and bed shear stress, which shaped functionally different communities in the inner and outer bay (Henriques et al., 2017). The inner-bay, more influenced by the estuary conditions of the Somme River, was historically dominated by benthopelagic planktivores likely adapted to turbulent waters that maintain planktonic suspension and limit competition by demersal 
fishes (Uiblein et al., 2003; Ware \& Thomson, 2005; Lindegren et al., 2012; Amorim et al., 2017). Outer-bay communities, associated with deeper waters and lower bed stress, were historically dominated by demersal benthivores likely adapted to the more stable marine conditions and stronger benthic energy channel (Blanchard et al., 2011; Lindegren et al., 2012; Griffiths et al., 2017). While these results follow known ecological patterns, we cannot exclude that differences between the inner and outer bay, particularly among pelagic species, could be influenced by different sampling protocols, as catchability changes with depth, sampling gear, and survey effort.

Despite these distinct differences between inner and outer-bay communities, temporal dynamics were relatively similar; the dominant functional groups, characterized by r-selected life history traits (e.g., low trophic level, low age and size at maturity, small offspring) declined dramatically in abundance. Population depletions in these groups caused a shift in dominance toward piscivores and benthopiscivores, leading to increases in trophic level, length at maturity, and age at maturity. As the major driver of changes in fish functional structure was likely rising sea surface temperatures, it appears that K-selected piscivores and benthopiscivores may be more resistant to warming in this, and possibly other ecosystems. Past studies have shown that K-selected fishes are highly impacted by fishing pressure but are often less responsive to climatic changes, while the opposite has been observed for r-selected fishes (Cheung et al., 2005; Graham et al., 2011; Simpson et al., 2011; Lynam et al., 2017). While the apparent climate-tolerance of large-bodied piscivores and benthopiscivores may explain their relative increase in the Bay of Somme, it is also likely that density-dependent changes in competition, predation, and reproduction contributed to the increase given severe drops in the previously dominant functional groups (Pace et al., 1999; Finke \& Denno, 2005; Bolnick et al., 2010). However, while we documented a relative increase in K-selected fishes under warming, we cannot exclude that warming will eventually impact these fishes but with 
a substantial time lag given their long lifespans and slow population turnover. Therefore an eventual decrease in $\mathrm{K}$-selected fishes is possible, particularly through reproduction or recruitment failure.

Previous investigation of the taxonomic structure of fish communities in the Bay of Somme found that long-term changes were largely explained by a decrease in cold-water species (Auber, Gohin, Goascoz, \& Schlaich, 2017). Here, by considering not only temperature preference but also life history and trophic ecology, we found that, beyond declines in cold-water species, life history traits best explained fish community responses to warming. This not only offers support for the functional-trait approach, but also suggests that fish respond to climate warming most prominently through differences in their life history strategies, which will be critical to understanding and modelling organismal responses to future climate change (Fossheim et al., 2015; Givan, Edelist, Sonin, \& Belmaker, 2018; Jones \& Cheung, 2018; Miller, Ota, Sumaila, Cisneros-Montemayor, \& Cheung, 2018).

Marine fish nurseries such as the Bay of Somme are dynamic ecosystems prone to fluctuating environmental conditions (Ippen, 1966; Cloern et al., 1983; Murrell et al., 2017). Estuaries in particular experience high variation in salinity and sedimentation due to freshwater input (Ippen, 1966). Such naturally-variable environments generally favor rselected fishes, which can rapidly respond to environmental fluctuations and flourish under dynamic conditions, whereas K-selected fishes are better competitors in stable environments (Pianka, 1970; Gadgil \& Solbrig, 1972; King \& McFarlane, 2003). However, r-selected fishes are potentially vulnerable to warming due to their high environmental responsiveness (Perry et al., 2005; Schweiger et al., 2008; Devictor et al., 2012). Although r-selected fishes can quickly recover from minor disturbances, the accelerated temperature increase in the Bay of Somme likely rendered the environment unfavorable, and impacted fishes may have emigrated to more suitable environments (Montero-Serra et al., 2014; Fossheim et al., 2015; 
McLean et al., in press). Strong correlation between SST and fish functional structure across several time lags further indicates a long-lasting impact and insufficient community inertia to rebound from such rapid environmental change. Although r-selected fishes quickly track environmental changes and can be highly impacted by warming in the short term (Simpson et al., 2011), they should have greater capacity for evolutionary adaptation given their rapid generation times (Rijnsdorp et al. 2009). Additionally, the impact of climate warming on rselected fishes is likely context dependent, and such fishes may flourish under climate warming in other ecosystems, especially by shifting poleward (McLean et al., in press). Consequently, lower-latitude ecosystems dominated by r-strategists will likely suffer declines under climate warming, as such environments may become unfavorable and fishes could shift poleward, whereas poleward ecosystems and ecosystems dominated by K-strategists may experience increases in r-selected fishes (McLean et al., in press; Nicolas et al., 2011).

While we documented a major decline in r-selected fishes in parallel to rapid warming, changes in trophic structure and ecosystem functioning may have exacerbated the shift in functional structure (Chevillot et al., 2016; Chevillot et al., 2018) Given the relative increase in K-selected fishes in parallel to the decline in r-selected fishes, it is possible that trophic re-balancing reinforced community changes as K-selected piscivores may have overexploited the already-declining r-strategists, leading to a negative feedback. Additionally, Kselected fishes that increased in abundance through time may have opportunistically shifted their diets toward alternative resources as r-selected fishes declined, further reorganizing ecosystem structure and functioning (Rooney, McCann, Gellner, \& Moore, 2006).

The Eastern English Channel (EEC) also underwent a major community shift in the late 1990s, characterized by a decline in r-selected pelagic fishes in response to AMOassociated warming (Auber et al., 2015; McLean et al., in press). The timing of the shift in the EEC corresponded to the shift documented here, and we additionally found that changes 
in functional structure between the two ecosystems were correlated (McLean unpublished data). Thus, it is likely that both the EEC and Bay of Somme were concurrently impacted by warming linked to the AMO, which lead to declines in fishes with environmentally-sensitive life history traits. However, the shift in the EEC occurred in the late 1990s, just prior to major declines in the bay, suggesting that biological responses in the EEC may have cascaded into the bay through recruitment failure (Ljunggren et al., 2010; Pankhurst \& Munday, 2011; Payne et al., 2009). Abrupt decreases in adult spawning fishes in the EEC could have a major impact on the bay, potentially driving the observed declines, as larval input would have diminished. In the 20 years following the shift in the EEC, the fishes that decreased in abundance have not recovered, and the ecosystem remains in an alternative state (Auber et al., 2015). Thus, it is also possible that population declines in the Bay of Somme acted as a negative feedback through reduced replenishment, limiting recovery potential (Pankhurst \& Munday, 2011; Reis-Santos et al., 2013).

While there is no commercial fishery in the Bay of Somme, historical and contemporary fishing pressure in the EEC likely impacted fish communities in the bay through changes in spawning stock biomass, larval production, and recruitment dynamics (Able, 2005; Gillanders, 2002; Lipcius et al., 2008; Vasconcelos, Reis-Santos, Costa, \& Cabral, 2011). We did not identify EEC landings as a primary driver of fish abundances in the bay, however, EEC landings over the last thirty years have been dominated by species such as herring, sprat, plaice, and sole, which all decreased in the bay over time. Although most stocks have had steady or declining landings in recent decades, continued pressure is certainly impacting fish communities in the EEC and its nurseries. Long and steady exploitation can also reduce fish abundances without showing any statistical association, especially if fishing is unsustainable. Furthermore, the English Channel and Northeast Atlantic are commercially important fishing grounds for multiple countries, and have a long 
history of over-exploitation (Myers, Hutchings, \& Barrowman, 1996; Pauly et al., 2002; Pauly \& Maclean, 2003). McHugh et al. (2011) and Molfese et al. (2014) showed a progressive shifting baseline in the English Channel due to a century of overfishing and fishing down the food web. This historical pressure progressively eroded the fish community from dominance by large, slow-growing species to small, quickly reproducing species and commercially-untargeted sharks and rays (Molfese, Beare, \& Hall-Spencer, 2014). Historical overfishing likely rendered both the EEC and its nurseries more vulnerable to climatic changes due to increased dominance by r-selected species, which are more tolerant to fishing but highly responsive to environmental changes (Auber et al. 2015; Kuo, Mandal, Yamauchi, \& Hsieh, 2016). Additionally, contemporary declines in fishing pressure likely facilitated the increase in K-selected species, such as Scophthalmus maximus, which was negatively correlated with landings in the outer bay. Altogether, past overfishing and continued exploitation likely impacted fish communities in the bay, through both direct removal of spawning adults, as well as indirect cascades in predation and competition, and synergistic effects between fishing and climate are possible (Daan, Gislason, G. Pope, \& C. Rice, 2005; McHugh, Sims, Partridge, \& Genner, 2011; Molfese, Beare, \& Hall-Spencer, 2014). However, given the strong correlation between warming and the decline in multiple rselected species, it appears that climate and not fishing was the main driver of changes at the community-scale. In support, our results highlight long-term decreases in fishes know to rapidly track environmental changes in parallel to increased dominance by species more vulnerable to fishing pressure.

Our results suggest that climate warming can profoundly alter functional structure in marine fish nurseries, which could have major implications for the stability of large marine ecosystems (LMEs) worldwide, as nurseries contribute to LME population maintenance (Beck et al., 2001; Seitz et al., 2014; Baptista et al., 2015; Liquete et al., 2016). In the Bay of 
Somme, declines in commercially-important species like plaice, sole, sprat and herring likely had negative, reinforcing impacts on fish stocks in the EEC (Auber et al., 2015, 2017). We found that fishes bearing r-selected functional traits were highly impacted by warming, leading to a shift in dominance toward alternative functional groups with higher length and age at maturity and higher trophic level (Perry et al., 2005; Jiguet et al., 2007; Devictor et al., 2012; Pecuchet et al., 2017). Our results therefore indicate that ongoing climate change may impact marine fish nurseries through declines in overall abundance and shifts in dominance toward fishes with environmentally-tolerant traits. While our study was limited in spatial extent, because estuaries and nursery habitats generally favor r-selected strategists, our findings are likely applicable to nurseries in other regions (Steele, Thorpe, \& Turekian, 2009; Teichert et al., 2017; Thomson \& Lehner, 1976). For example, Teichert et al. (2017) showed that estuaries across the Northeast Atlantic were dominated by opportunistic species with life history traits adapted to unstable environments, while Thomson et al. (1976) showed that even rocky, intertidal pools (used as nurseries by coastal species [Dias et al., 2016]) favor rselected strategists. Teichert et al. (2017) additionally showed that life history strategies were useful predictors of disturbance impacts on estuarine fish communities. Thus, dominance by opportunistic, r-selected fishes may indicate nurseries that could be heavily impacted by future warming.

Reorganizations in fish functional structure likely have major implications for ecosystem functioning as $\mathrm{r}$ and $\mathrm{K}$-strategists differ markedly in nutrient cycling, energy transfer, and biomass turnover (Rooney et al., 2006; Blanchard et al., 2011; Houk et al., 2017). Such changes will also have major implications for fisheries, as K-selected species are generally more vulnerable to fishing pressure (Cheung et al., 2005; Graham et al., 2011). For example, in the Bay of Somme, European seabass (Dicentrarchus labrax) and turbot (Scophthalmus maximus) had large increases in relative abundance, but both species are 
considered fishing-vulnerable (Cheung et al., 2005; Froese \& Pauly, 2012). Thus resource management should consider both the climatic and fishing vulnerability of communities to anticipate how future changes in environmental conditions and fishing pressure may impact marine ecosystems. In ecosystems dominated by species with r-selected functional traits, reduced fishing may alleviate the impacts of future warming. In contrast, as K-selected strategies appear more tolerant of warming, additional harvesting may be permissible for well-managed stocks with increasing abundances. With the emergence of functional-trait ecology, resource managers can also focus directly on fish functional structure, aiming to enhance response diversity through a balance of life history strategies with different environmental sensitivities (Izzo et al., 2016).

While we documented a marked shift in fish functional structure, a common weakness of functional-trait studies is the inability to capture intra-specific and ontogenetic trait variation (Petchey \& Gaston, 2006; Violle et al., 2007). Accordingly, we were unable to account for the influence of the relative composition of adults and juveniles on the spatial and temporal dynamics of functional structure. Future studies examining functional-trait dynamics in nurseries should incorporate demographic metrics such as size spectra and age distribution. Examining community changes through biomass rather than abundance could also provide insight on how juvenile demographics influence functional structure, and help link changes in functional structure to ecosystem processes (de Bello et al., 2010; Leps, de Bello, Lavorel, \& Berman, 2006). Emerging approaches integrating intra-specific and ontogenetic trait variability will help clarify how changes in size and age classes influence fish functional structure in nurseries.

This article is protected by copyright. All rights reserved. 
Marine fish nurseries are critical components of ecosystem landscapes, providing suitable habitats for the development of commercially important fish species (Gillanders et al., 2003; Dahlgren et al., 2006; Vasconcelos et al., 2010; Tournois et al., 2017). Nurseries are therefore extremely important to maintaining fish communities and ecosystems, making them priorities for resource management. Despite the importance of nurseries, few studies have examined the impacts of climate warming on functional structure in nursery communities. Our results indicate that communities dominated by fishes with r-selected traits are highly responsive to environmental change and may be more vulnerable to warming than previously recognized. Our results provide a critical warning, indicating that future climate change will likely affect marine fish nurseries worldwide, and immediate conservation efforts are needed to reduce the potential impacts. If large-scale studies confirm that marine fish nurseries are being heavily impacted by climate change globally, protection of fish nurseries must be immediately prioritized in ecosystem-based management.

\section{Acknowledgements}

We would like to thank all those who participated in the NOURSOM survey during the last thirty years. This study was supported by EDF, IFREMER (ECLIPSE project), Region Hauts-de-France (ECLIPSE project) and the Foundation for Research on Biodiversity (ECLIPSE project, contract no. astre 2014-10824).

This article is protected by copyright. All rights reserved. 


\section{References}

Able, K. W. (2005). A re-examination of fish estuarine dependence: Evidence for connectivity between estuarine and ocean habitats. Estuarine, Coastal and Shelf Science, 64(1), 5-17. https://doi.org/10.1016/j.ecss.2005.02.002

Aldridge, J. N., \& Davies, A. M. (1993). A high-resolution three dimensional hydrodynamic tidal model of the eastern Irish Sea. Journal of Physical Oceanography, 23, 207-224.

Amorim, E., Ramos, S., Elliott, M., Franco, A. \& Bordalo, A. A. (2017). Habitat loss and gain: Influence on habitat attractiveness for estuarine fish communities. Estuarine, Coastal and Shelf Science, 197, 244-257. https://doi.org/10.1016/j.ecss.2017.08.043.

Auber, A., Travers-Trolet, M., Villanueva, M. C. \& Ernande, B. (2015). Regime Shift in an Exploited Fish Community Related to Natural Climate Oscillations. PLoS One, 10(7). https://doi.org/10.1371/journal.pone.0129883.

Auber, A., Gohin, F., Goascoz, N. \& Schlaich, I. (2017). Decline of cold-water fish species in the Bay of Somme (English Channel, France) in response to ocean warming. Estuarine, Coastal and Shelf Science, 189, 189-202.

Baptista, J., Martinho, F., Nyitrai, D., Pardal, M. \& Dolbeth, M. (2015). Long-term functional changes in an estuarine fish assemblage. Marine Pollution Bulletin, 97(1-2), 125-134.

Beaugrand, G. (2004). The North Sea regime shift: evidence, causes, mechanisms and consequences. Progress in Oceanography, 60(2), 245-262.

Beck, M. W., Heck Jr, K. L., Able K. W., Childers D. L., Eggleston D. B., Gillanders B. M., ... Minello T. J. (2001). The identification, conservation, and management of estuarine and marine nurseries for fish and invertebrates: a better understanding of the habitats that serve as nurseries for marine species and the factors that create sitespecific variability in nursery quality will improve conservation and management of these areas. Bioscience, 51(8), 633-641.

Blanchard, J. L., Law, R., Castle, M. D. \& Jennings, S. (2011). Coupled energy pathways and the resilience of size-structured food webs. Theoretical Ecology, 4(3), 289-300.

Bœuf, G. \& Payan, P. (2001). How should salinity influence fish growth? Comparative Biochemistry and Physiology Part C: Toxicology \& Pharmacology, 130(4), 411-423. https://doi.org/10.1016/S1532-0456(01)00268-X.

Bolnick, D. I., Ingram, T., Stutz, W. E., Snowberg, L. K., Lau, O. L. \& Paull, J. S. (2010). Ecological release from interspecific competition leads to decoupled changes in population and individual niche width. Proceedings of the Royal Society B: Biological Sciences, 277(1689), 1789. https://doi.org/10.1098/rspb.2010.0018.

Borcard, D., Gillet, F. \& Legendre, P. (2011). Numerical ecology with R. Springer Science \& Business Media.

Bradshaw, W. E. \& Holzapfel, C. M. (2006). Evolutionary response to rapid climate change. Science, 312(5779), 1477-1478.

Gillanders, B. M. (2002). Connectivity between juvenile and adult fish populations: do adults remain near their recruitment estuaries? Marine Ecology Progress Series, 240, 215-223.

Buisson, L., Grenouillet, G., Villéger, S., Canal, J. \& Laffaille, P. (2013). Toward a loss of functional diversity in stream fish assemblages under climate change. Global Change Biology, 19(2), 387-400.

Burrows, M. T., Schoeman, D. S., Buckley, L. B., Moore, P., Poloczanska, E. S., Brander, K. M., ... Richardson, A. J. (2011). The Pace of Shifting Climate in Marine and $\begin{array}{llll}\text { Terrestrial } & \text { Ecosystems. } & \text { Science, } & 334(6056),\end{array}$ https://doi.org/10.1126/science.1210288.

This article is protected by copyright. All rights reserved. 
Cai, W., Borlace, S., Lengaigne, M., van Rensch, P., Collins, M., Vecchi, G., ... Jin F. F. (2014). Increasing frequency of extreme El Nino events due to greenhouse warming. Nature Climate Change, 4(2), 111-116.

Cheung, W. W. L., Pitcher T. J. \& Pauly D. (2005). A fuzzy logic expert system to estimate intrinsic extinction vulnerabilities of marine fishes to fishing. Biological Conservation, 124(1), 97-111. https://doi.org/10.1016/j.biocon.2005.01.017.

Chevillot, X., Pierre, M., Rigaud, A., Drouineau, H., Chaalali, A., Sautour, B., \& Lobry, J. (2016). Abrupt shifts in the Gironde fish community: an indicator of ecological changes in an estuarine ecosystem. Marine Ecology Progress Series, 549, 137-151.

Chevillot, X., Tecchio, S., Chaalali, A., Lassalle, G., Selleslagh, J., Castelnaud, G., ... Lobry, J. (2018). Global Changes Jeopardize the Trophic Carrying Capacity and Functioning of Estuarine Ecosystems. Ecosystems. https://doi.org/10.1007/s10021-018-0282-9

Clarke, K. R. (1993). Non-parametric multivariate analyses of changes in community structure. Australian Journal of Ecology, 18(1), 117-143. https://doi.org/10.1111/j.1442-9993.1993.tb00438.x

Clifford, P., Richardson, S., \& Hemon, D. (1989). Assessing the Significance of the Correlation between Two Spatial Processes. Biometrics, 45(1), 123-134. https://doi.org/10.2307/2532039

Cloern, J. E., Alpine, A. E., Cole, B. E., Wong, R. L., Arthur, J. F. \& Ball, M. D. (1983). River discharge controls phytoplankton dynamics in the northern San Francisco Bay estuary. Estuarine, Coastal and Shelf Science, 16(4), 415-429.

Cochard, M. L. (2002). Manuel des protocoles de campagne halieutique. Campagnes IGA Penly: Macrofaune halieutique. DRV/RH/DT/2002-009.

Comte, L. \& Olden, J. D. (2017). Climatic vulnerability of the world's freshwater and marine fishes. Nature Climate Change, 7, 718 .

Daan, N., Gislason, H., Pope, J. G., \& Rice, J. C. (2005). Changes in the North Sea fish community: evidence of indirect effects of fishing? ICES Journal of Marine Science, 62(2), 177-188. https://doi.org/10.1016/j.icesjms.2004.08.020

Dahlgren, C. P., Kellison, G. T., Adams, A. J., Gillanders, B. M., Kendall, M. S., Layman, C. A., ... Serafy, J. E. (2006). Marine nurseries and effective juvenile habitats: concepts and applications. Marine Ecology Progress Series, 312, 291-295.

de Bello, F., Lavorel, S., Díaz, S., Harrington, R., Cornelissen, J. H. C., Bardgett, R. D., ... Harrison, P. A. (2010). Towards an assessment of multiple ecosystem processes and services via functional traits. Biodiversity and Conservation, 19(10), 2873-2893. https://doi.org/10.1007/s10531-010-9850-9

Devictor, V., Van Swaay, C., Brereton, T., Chamberlain, D., Heliölä J., Herrando, S., ... Roy, D. B. (2012). Differences in the climatic debts of birds and butterflies at a continental scale. Nature Climate Change, 2(2), 121.

Dias, M., Roma, J., Fonseca, C., Pinto, M., Cabral, H. N., Silva, A., \& Vinagre, C. (2016). Intertidal pools as alternative nursery habitats for coastal fishes. Marine Biology Research, 12(4), 331-344. https://doi.org/10.1080/17451000.2016.1143106

Dickson, R. (2000). The NAO: the dominant atmospheric process affecting oceanic variability in home, middle and distant waters of European Salmon. In: The Ocean life of Atlantic Salmon: Environmental and biological factors influencing survival.

Diffenbaugh, N. S., Singh, D., Mankin, J. S., Horton, D. E., Swain, D. L., Touma, D., ... Rajaratnam, B. (2017). Quantifying the influence of global warming on unprecedented extreme climate events. Proceedings of the National Academy of Sciences, 114(19), 4881. https://doi.org/10.1073/pnas.1618082114.

Dreves, L., Abernot-Le Gac, C., Antajan, E., Clabaut, P., Claquin, P., Cochard, M. L., ...Thillaye Du Boullay, H. (2010). Synthèse hydrobiologique du site électronucléaire

This article is protected by copyright. All rights reserved. 
de

http://archimer.ifremer.fr/doc/00026/13688/

Dulvy, N. K., Rogers, S. I., Jennings, S., Stelzenmller, V., Dye, S. R. \& Skjoldal, H. R. (2008). Climate change and deepening of the North Sea fish assemblage: a biotic indicator of warming seas. Journal of Applied Ecology, 45(4), 1029-1039. https://doi.org/10.1111/j.1365-2664.2008.01488.x.

Edwards, M., Beaugrand, G., Helaouët, P., Alheit, J. \& Coombs, S. (2013). Marine ecosystem response to the Atlantic Multidecadal Oscillation. PLoS One, 8(2), e57212.

Enfield, D. B., Mestas-Nuñez, A. M. \& Trimble, P. J. (2001). The Atlantic multidecadal oscillation and its relation to rainfall and river flows in the continental US. Geophysical Research Letters, 28(10), 2077-2080.

Engelhard, G. H., Ellis, J. R., Payne, M. R., ter Hofstede, R. \& Pinnegar, J. K. (2011). Ecotypes as a concept for exploring responses to climate change in fish assemblages. ICES Journal of Marine Science, 68(3), 580-591. https://doi.org/10.1093/icesjms/fsq183.

Finke, D. L. \& Denno, R. F. (2005). Predator diversity and the functioning of ecosystems: the role of intraguild predation in dampening trophic cascades. Ecology Letters, 8(12), 1299-1306. https://doi.org/10.1111/j.1461-0248.2005.00832.x.

Fossheim, M., Primicerio, R., Johannesen, E., Ingvaldsen, R. B., Aschan, M. M. \& Dolgov, A. V. (2015). Recent warming leads to a rapid borealization of fish communities in the Arctic. Nature Climate Change, 5, 673.

Frainer, A., Primicerio, R., Kortsch, S., Aune, M., Dolgov, A. V., Fossheim, M. \& Aschan, M. M. (2017). Climate-driven changes in functional biogeography of Arctic marine fish communities. Proceedings of the National Academy of Sciences, 114(46), 1220212207.

Froese, R. \& Pauly, D. (2012). FishBase (www database). Available at: http://www. fishbase. org (accessed Mar 2017).

Frölicher, T. L., Fischer, E. M., \& Gruber, N. (2018). Marine heatwaves under global warming. Nature, 560(7718), 360-364. https://doi.org/10.1038/s41586-018-0383-9

Gadgil, M. \& Solbrig, O. T. (1972). The concept of r-and K-selection: evidence from wild flowers and some theoretical considerations. The American Naturalist, 106(947), 1431.

Gallagher, R. V., Hughes, L. \& Leishman, M. R. (2013). Species loss and gain in communities under future climate change: consequences for functional diversity. Ecography, 36(5), 531-540. https://doi.org/10.1111/j.1600-0587.2012.07514.x.

Gillanders, B. M., Able, K. W., Brown, J. A., Eggleston, D. B. \& Sheridan, P. F. (2003). Evidence of connectivity between juvenile and adult habitats for mobile marine fauna: an important component of nurseries. Marine Ecology Progress Series, 247, 281-295.

Givan, O., Edelist, D., Sonin, O. \& Belmaker, J. (2018). Thermal affinity as the dominant factor changing Mediterranean fish abundances. Global Change Biology, 24(1), 8089.

Gohin, F. (2011). Annual cycles of chlorophyll-a, non-algal suspended particulate matter, and turbidity observed from space and in-situ in coastal waters. Ocean Science, 7(5), 705.

Graham, N. A. J., Chabanet, P., Evans, R. D., Jennings, S., Letourneur, Y., Aaron, MacNeil M., ... Wilson, S. K. (2011). Extinction vulnerability of coral reef fishes. Ecology Letters, 14(4), 341-348. https://doi.org/10.1111/j.1461-0248.2011.01592.x.

Griffiths, J. R., Kadin, M., Nascimento, F. J. A., Tamelander, T., Törnroos, A., Bonaglia, S., ... Winder, M. (2017). The importance of benthic-pelagic coupling for marine ecosystem functioning in a changing world. Global Change Biology, 23(6), 21792196. https://doi.org/10.1111/gcb.13642.

This article is protected by copyright. All rights reserved. 
Hallett, T. B., Coulson, T., Pilkington, J. G., Clutton-Brock, T. H., Pemberton, J. M., \& Grenfell, B. T. (2004). Why large-scale climate indices seem to predict ecological processes better than local weather. Nature, 430, 71.

Henriques, S., Guilhaumon, F., Villéger, S., Amoroso, S., França, S., Pasquaud, S., ... Vasconcelos, R. P. (2017). Biogeographical region and environmental conditions drive functional traits of estuarine fish assemblages worldwide. Fish and Fisheries, 18(4), 752-771.

Henson, S. A., Beaulieu, C., Ilyina, T., John, J. G., Long, M., Séférian, R., ... Sarmiento, J. L. (2017). Rapid emergence of climate change in environmental drivers of marine ecosystems. Nature Communications, 8, 14682.

Hermant, M., Lobry, J., Bonhommeau, S., Poulard, J.-C., \& Le Pape, O. (2010). Impact of warming on abundance and occurrence of flatfish populations in the Bay of Biscay (France). Proceedings of the Seventh International Symposium on Flatfish Ecology, Part I, 64(1), 45-53. https://doi.org/10.1016/j.seares.2009.07.001

Houk, P., Cuetos-Bueno, J., Kerr, A. \& McCann, K. (2017). Linking fishing pressure with ecosystem thresholds and food web stability on coral reefs. Ecological Monographs, $88,109-119$.

Hughes, T. P., Anderson, K. D., Connolly, S. R., Heron, S. F., Kerry, J. T., Lough, J. M., ... Wilson, S. K. (2018). Spatial and temporal patterns of mass bleaching of corals in the Anthropocene. Science, 359(6371), 80. https://doi.org/10.1126/science.aan8048.

Hurrell, J. W., Kushnir, Y., Ottersen, G. \& Visbeck, M. (2003). An overview of the North Atlantic oscillation. In: The North Atlantic Oscillation: climatic significance and environmental impact, 1-35.

ICES. Catch Statistics Database. Retrieved from http://www.ices.dk/marine-data/datasetcollections/Pages/Fish-catch-and-stock-assessment.aspx. (accessed July 2017).

Ippen, A. T. (1966). Estuary and coastline hydrodynamics. Iowa State University Press.

Izzo, C., Doubleday, Z. A., Grammer, G. L., Barnes, T. C., Delean, S., Ferguson, G. J., ... Gillanders, B. M. (2016). Multi-species response to rapid environmental change in a large estuary system: A biochronological approach. Ecological Indicators, 69, 739748. https://doi.org/10.1016/j.ecolind.2016.05.019

Jiguet, F., Gadot, A., Julliard, R., Newson, S. E. \& Couvet, D. (2007). Climate envelope, life history traits and the resilience of birds facing global change. Global Change Biology, 13(8), 1672-1684.

Jones, M. C., \& Cheung, W. W. (2018). Using fuzzy logic to determine the vulnerability of marine species to climate change. Global Change Biology, 24(2), 719-731.

King, J. R. \& McFarlane, G. A. (2003). Marine fish life history strategies: applications to fishery management. Fisheries Management and Ecology, 10(4), 249-264.

Kjelland, M. E., Woodley, C. M., Swannack, T. M. \& Smith, D. L. (2015). A review of the potential effects of suspended sediment on fishes: potential dredging-related physiological, behavioral, and transgenerational implications. Environment Systems and Decisions, 35(3), 334-350. https://doi.org/10.1007/s10669-015-9557-2.

Kuo, T. C., Mandal, S., Yamauchi, A., \& Hsieh, C. (2016). Life history traits and exploitation affect the spatial mean-variance relationship in fish abundance. Ecology, 97(5), 12511259. https://doi.org/10.1890/15-1270.1

Le Pape, O. (2005). Les habitats halieutiques essentiels en milieu côtier Les identifier, comprendre leur fonctionnement et suivre leur qualité pour mieux gérer et pérenniser les ressources marines exploitées. Univeristé de Bretagne Occidentale. Retrieved from http://halieutique.agrocampus-ouest.fr/pdf/743.pdf

This article is protected by copyright. All rights reserved. 
Leps, J., de Bello, F., Lavorel, S., \& Berman, S. (2006). Quantifying and interpreting functional diversity of natural communities: practical considerations matter. Preslia, $78(4), 481-501$.

Lindegren, M., Blenckner, T. \& Stenseth, N. C. (2012). Nutrient reduction and climate change cause a potential shift from pelagic to benthic pathways in a eutrophic marine ecosystem. Global Change Biology, 18(12), 3491-3503. https://doi.org/10.1111/j.1365-2486.2012.02799.x.

Lipcius, R. N., Eggleston, D. B., Schreiber, S. J., Seitz, R. D., Shen, J., Sisson, M., ... Wang, H. V. (2008). Importance of Metapopulation Connectivity to Restocking and Restoration of Marine Species. Reviews in Fisheries Science, 16(1-3), 101-110. https://doi.org/10.1080/10641260701812574

Liquete, C., Cid N., Lanzanova, D., Grizzetti, B. \& Reynaud, A. (2016). Perspectives on the link between ecosystem services and biodiversity: The assessment of the nursery function. Ecological Indicators, $249-257$. https://doi.org/10.1016/j.ecolind.2015.11.058.

Ljunggren, L., Sandström, A., Bergström, U., Mattila, J., Lappalainen, A., Johansson, G., ... Eriksson, B. K. (2010). Recruitment failure of coastal predatory fish in the Baltic Sea coincident with an offshore ecosystem regime shift. ICES Journal of Marine Science, 67(8), 1587-1595. https://doi.org/10.1093/icesjms/fsq109

Loarie, S. R., Duffy, P. B., Hamilton, H., Asner, G. P., Field, C. B. \& Ackerly, D. D. (2009). The velocity of climate change. Nature, 462, 1052.

Lynam, C. P., Llope, M., Möllmann, C., Helaouët, P., Bayliss-Brown, G. A. \& Stenseth, N. C. (2017). Interaction between top-down and bottom-up control in marine food webs. Proceedings of the National Academy of Sciences, 114(8), 1952-1957.

McLean, M., Mouillot, D., Lindegren, M., Engelhard, G., Villéger, S., Marchal, P., ... Auber, A. (In press). A climate-driven functional inversion of connected marine ecosystems. Current Biology.

McHugh, M., Sims, D. W., Partridge, J. C., \& Genner, M. J. (2011). A century later: Longterm change of an inshore temperate marine fish assemblage. Journal of Sea Research, 65(2), 187-194. https://doi.org/10.1016/j.seares.2010.09.006

Miller, D. D., Ota, Y., Sumaila, U. R., Cisneros-Montemayor, A. M., \& Cheung, W. W. (2018). Adaptation strategies to climate change in marine systems. Global Change Biology, 24(1), 1-14.

Molfese, C., Beare, D., \& Hall-Spencer, J. M. (2014). Overfishing and the Replacement of Demersal Finfish by Shellfish: An Example from the English Channel. PLoS One, 9(7), e101506. https://doi.org/10.1371/journal.pone.0101506

Montero-Serra, I., Edwards M., \& Genner, M. J. (2014). Warming shelf seas drive the subtropicalization of European pelagic fish communities. Global Change Biology, 21(1), 144-153. https://doi.org/10.1111/gcb.12747.

Moore., G. W. K., Halfar, J., Majeed, H., Adey, W. \& Kronz, A. (2017). Amplification of the Atlantic Multidecadal Oscillation associated with the onset of the industrial-era warming. Scientific Reports, 7, 40861. https://doi.org/10.1038/srep40861.

Mouillot, D., Graham, N. A. J., Villéger, S., Mason, N. W. H. \& Bellwood, D. R. (2013). A functional approach reveals community responses to disturbances. Trends in Ecology \& Evolution, 28(3), 167-177. https://doi.org/10.1016/j.tree.2012.10.004.

Murrell, M. C., Caffrey, J. M., Marcovich, D. T., Beck, M. W., Jarvis, B. M. \& Hagy, J. D. (2017). Seasonal oxygen dynamics in a warm temperate estuary: effects of hydrologic variability on measurements of primary production, respiration, and net metabolism. Estuaries and Coasts, 1-18.

This article is protected by copyright. All rights reserved. 
Myers, R. A., Hutchings, J. A., \& Barrowman, N. (1996). Hypotheses for the decline of cod in the North Atlantic. Marine Ecology Progress Series, 138, 293-308.

Nagelkerken, I., Huebert, K., Serafy, J., Grol, M., Dorenbosch, M. \& Bradshaw, C. (2017). Highly localized replenishment of coral reef fish populations near nursery habitats. Marine Ecology Progress Series, 568, 137-150.

Nash, K. L., Cvitanovic, C., Fulton, E. A., Halpern, B. S., Milner-Gulland, E. J., Watson, R. A. \& Blanchard, J. L. (2017). Planetary boundaries for a blue planet. Nature Ecology \& Evolution, 1(11), 1625-1634. https://doi.org/10.1038/s41559-017-0319-z.

Nicolas, D., Lobry, J., Le Pape, O., \& Boët, P. (2010). Functional diversity in European estuaries: Relating the composition of fish assemblages to the abiotic environment. Estuarine, Coastal and Shelf Science, 88(3), 329-338. https://doi.org/10.1016/j.ecss.2010.04.010

Nicolas, D., Chaalali, A., Drouineau, H., Lobry, J., Uriarte, A., Borja, A., \& Boët, P. (2011). Impact of global warming on European tidal estuaries: some evidence of northward migration of estuarine fish species. Regional Environmental Change, 11(3), 639-649. https://doi.org/10.1007/s10113-010-0196-3

Pace, M. L., Cole, J. J., Carpenter, S. R. \& Kitchell, J. F. (1999). Trophic cascades revealed in diverse ecosystems. Trends in Ecology \& Evolution, 14(12), 483-488.

Pankhurst, N. W., \& Munday, P. L. (2011). Effects of climate change on fish reproduction and early life history stages. Marine and Freshwater Research, 62(9), 1015-1026.

Pauly, D., Christensen, V., Guénette, S., Pitcher, T. J., Sumaila, U. R., Walters, C. J., ... Zeller, D. (2002). Towards sustainability in world fisheries. Nature, 418(6898), 689695.

Pauly, D., \& Maclean, J. (2003). In a perfect ocean: the state of fisheries and ecosystems in the North Atlantic Ocean (Vol. 1). Island Press.

Payne, M. R., Hatfield, E. M. C., Dickey-Collas, M., Falkenhaug, T., Gallego, A., Gröger, J., ... Nash, R. D. M. (2009). Recruitment in a changing environment: the 2000s North Sea herring recruitment failure. ICES Journal of Marine Science, 66(2), 272-277. https://doi.org/10.1093/icesjms/fsn211

Pecuchet, L., Lindegren, M., Hidalgo, M., Delgado, M., Esteban, A., Fock, H. O., ... Payne, M. R. (2017). From traits to life-history strategies: Deconstructing fish community composition across European seas. Global Ecology and Biogeography, 25, 812-822.

Perry, A. L., Low, P. J., Ellis, J. R. \& Reynolds, J. D. (2005). Climate change and distribution shifts in marine fishes. Science, 308(5730), 1912-1915.

Petchey, O. L., \& Gaston, K. J. (2006). Functional diversity: back to basics and looking forward. Ecology Letters, 9(6), 741-758. https://doi.org/10.1111/j.14610248.2006.00924.X

Petitgas, P., Rijnsdorp A. D., Dickey-Collas M., Engelhard G. H., Peck M. A., Pinnegar J. K., ... Nash R. D. M. (2013). Impacts of climate change on the complex life cycles of fish. Fisheries Oceanography, 22(2), 121-139. https://doi.org/10.1111/fog.12010.

Pianka, E. R. (1970). On r- and K-Selection. The American Naturalist, 104(940), 592-597. https://doi.org/10.1086/282697.

Poloczanska, E. S., Brown, C. J., Sydeman, W. J., Kiessling, W., Schoeman, D. S., Moore, P. J., ... Burrows, M. T. (2013). Global imprint of climate change on marine life. Nature Climate Change, 3(10), 919-925.

Rayner, N., Parker, D. E., Horton, E., Folland, C., Alexander, L., Rowell, D., ... Kaplan, A. (2003). Global analyses of sea surface temperature, sea ice, and night marine air temperature since the late nineteenth century. Journal of Geophysical Research: Atmospheres, 108(D14).

This article is protected by copyright. All rights reserved. 
Reis-Santos, P, Tanner, S. E., Vasconcelos, R. P., Elsdon, T. S., Cabral, H. N., \& Gillanders, B. M. (2013). Connectivity between estuarine and coastal fish populations: contributions of estuaries are not consistent over time. Marine Ecology Progress Series, 491, 177-186.

Rijnsdorp, A. D., Peck, M. A., Engelhard, G. H., Möllmann, C., \& Pinnegar, J. K. (2009). Resolving the effect of climate change on fish populations. ICES Journal of Marine Science, 66(7), 1570-1583. https://doi.org/10.1093/icesjms/fsp056

Rooney, N., McCann, K., Gellner, G. \& Moore, J. C. (2006). Structural asymmetry and the stability of diverse food webs. Nature, 442(7100), 265-269. https://doi.org/10.1038/nature04887.

Rutterford, L. A., Simpson, S. D., Jennings, S., Johnson, M. P., Blanchard, J. L., Schön, P.-J., ... Genner M. J. (2015). Future fish distributions constrained by depth in warming seas. Nature Climate Change, 5, 569.

Rybarczyk, H., Elkaim, B., Ochs, L. \& Loquet, N. (2003). Analysis of the trophic network of a macrotidal ecosystem: the Bay of Somme (Eastern Channel). Estuarine, Coastal and Shelf Science, 58(3), 405-421. https://doi.org/10.1016/S0272-7714(02)00294-9.

Saulquin, B. \& Gohin, F. (2010). Mean seasonal cycle and evolution of the sea surface temperature from satellite and in situ data in the English Channel for the period 19862006. International Journal of Remote Sensing, 31(15), 4069-4093. https://doi.org/10.1080/01431160903199155.

Schofield, O., Ducklow, H. W., Martinson, D. G., Meredith, M. P., Moline, M. A. \& Fraser, W. R. (2010). How Do Polar Marine Ecosystems Respond to Rapid Climate Change? Science, 328(5985), 1520-1523. https://doi.org/10.1126/science.1185779.

Schweiger, O., Settele, J., Kudrna, O., Klotz, S. \& Kühn, I. (2008). Climate change can cause spatial mismatch of trophically interacting species. Ecology, 89(12), 3472-3479.

Seitz, R. D., Wennhage, H., Bergström, U., Lipcius, R. N. \& Ysebaert, T. (2014). Ecological value of coastal habitats for commercially and ecologically important species. ICES Journal of Marine Science, 71(3), 648-665. https://doi.org/10.1093/icesjms/fst152.

Shaffer, G., Olsen, S. M. \& Pedersen, J. O. P. (2009). Long-term ocean oxygen depletion in response to carbon dioxide emissions from fossil fuels. Nature Geoscience, 2(2), 105109.

Simpson, S. D., Jennings, S., Johnson, M. P., Blanchard, J. L., Schön, P.-J., Sims, D. W., \& Genner, M. J. (2011). Continental Shelf-Wide Response of a Fish Assemblage to Rapid Warming of the Sea. Current Biology, 21(18), 1565-1570. https://doi.org/10.1016/j.cub.2011.08.016

Sloterdijk, H., Brehmer, P., Sadio, O., Müller, H., Döring, J. \& Ekau, W. (2017). Composition and structure of the larval fish community related to environmental parameters in a tropical estuary impacted by climate change. Estuarine, Coastal and Shelf Science, 197, 10-26. https://doi.org/10.1016/j.ecss.2017.08.003.

Steele, J. H., Thorpe, S. A., \& Turekian, K. K. (2009). Encyclopedia of Ocean Sciences. Elsevier.

Sunday, J. M., Fabricius, K. E., Kroeker, K. J., Anderson, K. M., Brown, N. E., Barry, J. P., ... Harley, C. D. G. (2016). Ocean acidification can mediate biodiversity shifts by changing biogenic habitat. Nature Climate Change, 7, 81.

Teichert, N., Pasquaud, S., Borja, A., Chust, G., Uriarte, A., \& Lepage, M. (2017). Living under stressful conditions: Fish life history strategies across environmental gradients in estuaries. Estuarine, Coastal and Shelf Science, 188, 18-26. https://doi.org/10.1016/j.ecss.2017.02.006

This article is protected by copyright. All rights reserved. 
Thomson, D. A., \& Lehner, C. E. (1976). Resilience of a rocky intertidal fish community in a physically unstable environment. Journal of Experimental Marine Biology and Ecology, 22(1), 1-29. https://doi.org/10.1016/0022-0981(76)90106-4

Ting, M., Kushnir, Y., Seager, R. \& Li, C. (2009). Forced and internal twentieth-century SST trends in the North Atlantic. Journal of Climate, 22(6), 1469-1481.

Tolan, J. M. (2007). El Niño-Southern Oscillation impacts translated to the watershed scale: Estuarine salinity patterns along the Texas Gulf Coast, 1982 to 2004. Estuarine, Coastal and Shelf Science, 72(1), 247-260. https://doi.org/10.1016/j.ecss.2006.10.018

Tournois, J., Darnaude, A. M., Ferraton, F., Aliaume, C., Mercier, L. \& McKenzie, D. J. (2017). Lagoon nurseries make a major contribution to adult populations of a highly prized coastal fish. Limnology and Oceanography, 62(3), 1219-1233. https://doi.org/10.1002//no.10496.

Uiblein, F., Lorance, P. \& Latrouite, D. (2003). Behaviour and habitat utilisation of seven demersal fish species on the Bay of Biscay continental slope, NE Atlantic. Marine Ecology Progress Series, 257, 223-232.

Vasconcelos, R., Reis-Santos, P., Maia, A., Fonseca, V., França, S., Wouters, N., ... Cabral, H. (2010). Nursery use patterns of commercially important marine fish species in estuarine systems along the Portuguese coast. Estuarine, Coastal and Shelf Science, 86(4), 613-624.

Vasconcelos, R. P., Reis-Santos, P., Costa, M. J., \& Cabral, H. N. (2011). Connectivity between estuaries and marine environment: Integrating metrics to assess estuarine nursery function. Ecological Indicators, 11(5), 1123-1133. https://doi.org/10.1016/j.ecolind.2010.12.012

Villéger, S., Brosse, S., Mouchet, M., Mouillot, D. \& Vanni, M. J. (2017). Functional ecology of fish: current approaches and future challenges. Aquatic Sciences, 1-19.

Violle, C., Navas, M.L., Vile, D., Kazakou, E., Fortunel, C., Hummel, I., \& Garnier, E. (2007). Let the concept of trait be functional! Oikos, 116(5), 882-892. https://doi.org/10.1111/j.0030-1299.2007.15559.x

Ware, D. M. \& Thomson, R. E. (2005). Bottom-Up Ecosystem Trophic Dynamics Determine Fish Production in the Northeast Pacific. Science, 308(5726), 1280. https://doi.org/10.1126/science.1109049.

Wiens, J. J. (2016). Climate-related local extinctions are already widespread among plant and animal species. PLoS biology, 14(12), e2001104.

This article is protected by copyright. All rights reserved. 


\section{Tables}

TABLE 1 Functional traits used to characterize fish functional structure.

\begin{tabular}{|c|c|c|c|}
\hline $\begin{array}{l}\text { Functional } \\
\text { Trait }\end{array}$ & Category & Type & Units \\
\hline $\begin{array}{l}\text { Length at } \\
\text { maturity }\end{array}$ & Life history & Numeric & Total length $(\mathrm{cm})$ \\
\hline Age at maturity & Life history & Numeric & Years \\
\hline Parental care & Life history & $\begin{array}{l}\text { Ordered } \\
\text { factor }\end{array}$ & $\begin{array}{l}1=\text { pelagic egg, } 2=\text { benthic egg, } 3=\text { clutch } \\
\text { hider, } 4=\text { clutch guarder, } 5=\text { live bearer }\end{array}$ \\
\hline Fecundity & Life history & Numeric & Number of offspring per female \\
\hline Offspring size & Life history & Numeric & Total length or diameter $(\mathrm{cm})$ \\
\hline Trophic guild & $\begin{array}{l}\text { Trophic } \\
\text { ecology }\end{array}$ & Factor & $\begin{array}{l}\text { Benthivore, benthopiscivore, detritivore, } \\
\text { piscivore, planktivore }\end{array}$ \\
\hline Trophic level & $\begin{array}{l}\text { Trophic } \\
\text { ecology }\end{array}$ & Numeric & Level (unit-less) \\
\hline $\begin{array}{l}\text { Water column } \\
\text { position }\end{array}$ & Habitat use & Factor & $\begin{array}{l}\text { Benthopelagic, demersal, epipelagic, } \\
\text { pelagic, reef-associated }\end{array}$ \\
\hline $\begin{array}{l}\text { Temperature } \\
\text { preference }\end{array}$ & Habitat use & Numeric & Degrees Celsius \\
\hline
\end{tabular}

This article is protected by copyright. All rights reserved. 
TABLE 2 Changes in community-weighted mean (CWM) trait values in inner and outer-bay communities.

\begin{tabular}{|c|c|c|c|c|c|c|}
\hline & Inner Bay & & & Outer Bay & & \\
\hline Functional Trait & Dynamic & $F_{1,24}$-value & P-value & Dynamic & $F_{1,24}$-value & P-value \\
\hline Age mature & Increase & 21.6 & 0.0001 & Increase & 14.67 & 0.0008 \\
\hline Length mature & Increase & 11.87 & 0.002 & Increase & 15.36 & 0.0006 \\
\hline Benthopiscivore & Increase & 11.71 & 0.002 & Increase & 5.08 & 0.03 \\
\hline Fecundity & Increase & 6.14 & 0.02 & Increase & 7.66 & 0.01 \\
\hline Piscivore & Increase & 5.33 & 0.02 & Increase & 20.22 & 0.0001 \\
\hline Trophic level & & & & Increase & 13.92 & 0.001 \\
\hline Temp. preference & & & & Increase & 5.79 & 0.02 \\
\hline Parental care & Decrease & 20.37 & 0.0001 & & & \\
\hline Benthivore & & & & Decrease & 6.9 & 0.01 \\
\hline Planktivore & Decrease & 14.09 & 0.001 & & & \\
\hline
\end{tabular}

\section{Figure Legends}

FIGURE 1 Map of the Bay of Somme showing all sampling sites throughout the entire time series, with colors corresponding to inner and outer-bay functional clusters. Survey zones and their corresponding depths are shown. For maps of environmental variables used in this study please see Figure S2.

FIGURE 2 Fish functional space showing community trait structure along with temporal changes in species' abundances. a) Functional trait composition for the overall Bay of Somme fish community. b, c) Species positions' in functional space are plotted (points) in each cluster and sizes are scaled by the log of mean abundances throughout the overall time series. Convex hulls (colored polygons) represent the functional space containing all species in each cluster. d) Three-year moving averages and standard deviations of abundance-weighted community centroids along PCOA axis 2 in each cluster. e, f) Changes in the abundances of all species in each cluster; sizes are scaled by the log of the rate of change in species' abundances, and colors indicate whether abundances decreased or increased.

This article is protected by copyright. All rights reserved. 
FIGURE 3 Principal component analysis (PCA) biplots showing temporal changes in fish functional structure in inner (a) and outer-bay (b) communities, along with the temporal dynamics (3-year moving averages and standard deviations) of AMO, SST, PCA axis 1, and overall fish abundance (dashed line) in each cluster (c, d). Note PCA 1 scores are shown in reverse order (positive to negative) to highlight temporal chronology in (a) and (b), and to compare trends with AMO and SST in (c) and (d).

FIGURE 4 Results of partial redundancy analysis showing significant environmental drivers of differences in fish functional structure between inner and outer-bay clusters.

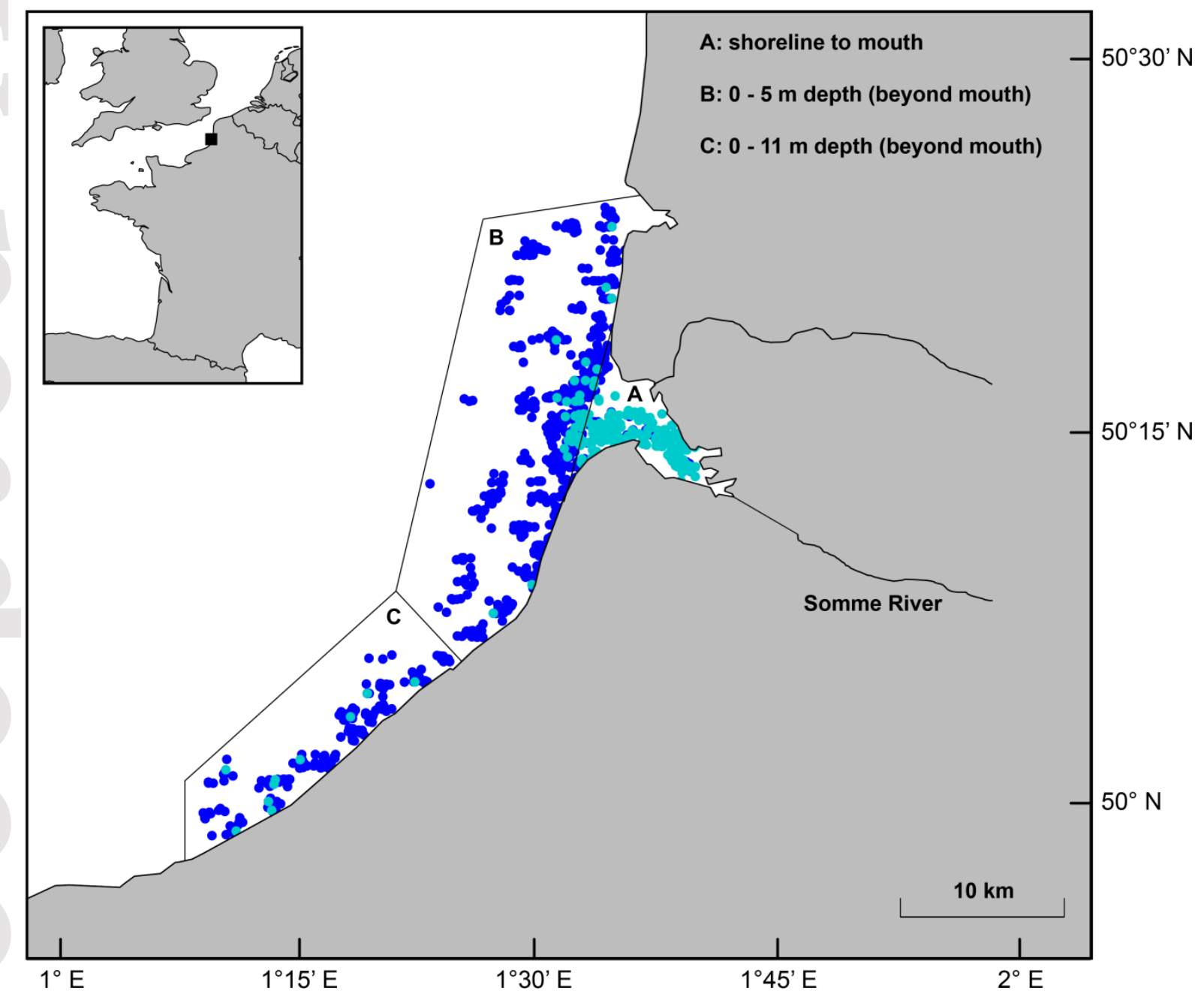

This article is protected by copyright. All rights reserved. 
(a)

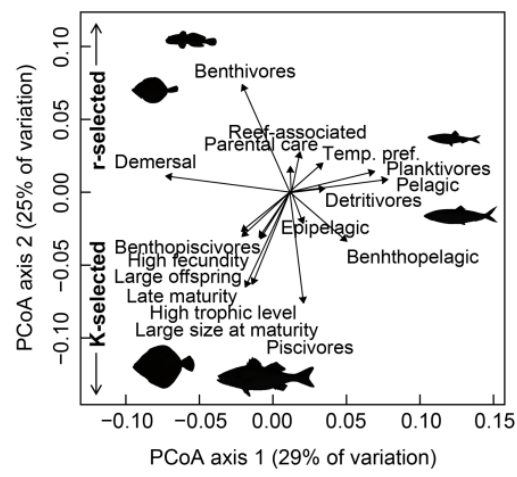

(d)

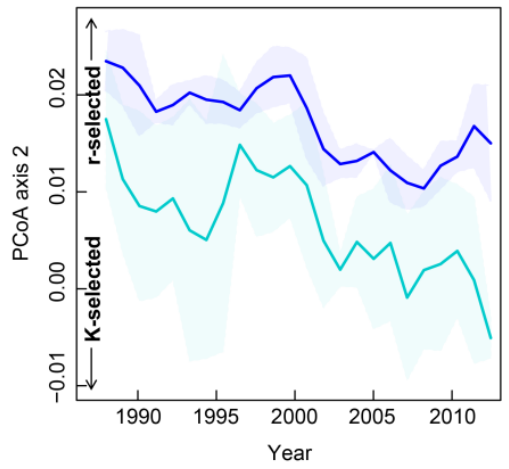

(b)

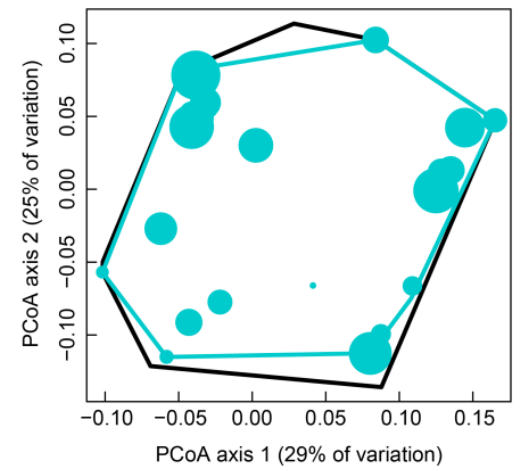

(e)

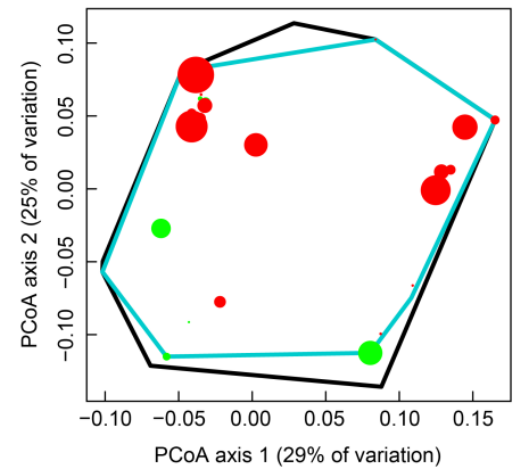

(c)

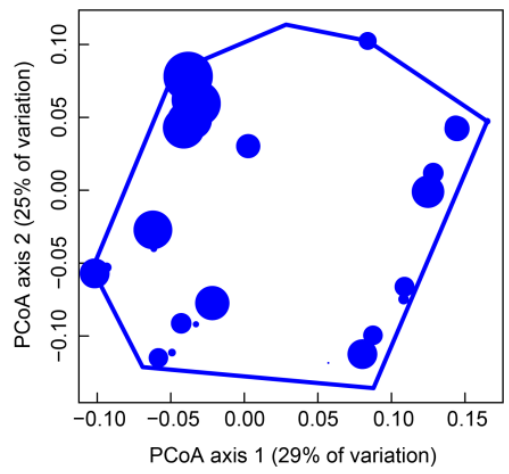

(f)

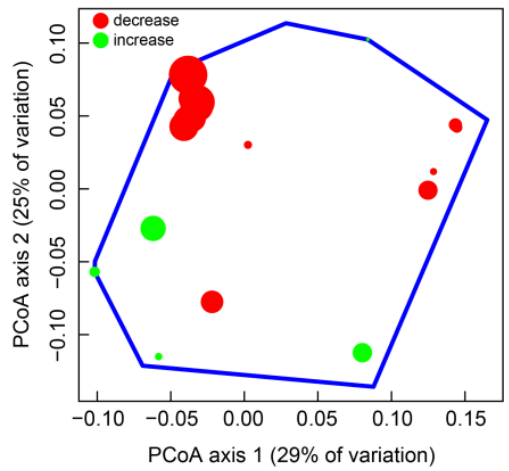

This article is protected by copyright. All rights reserved. 
(a)

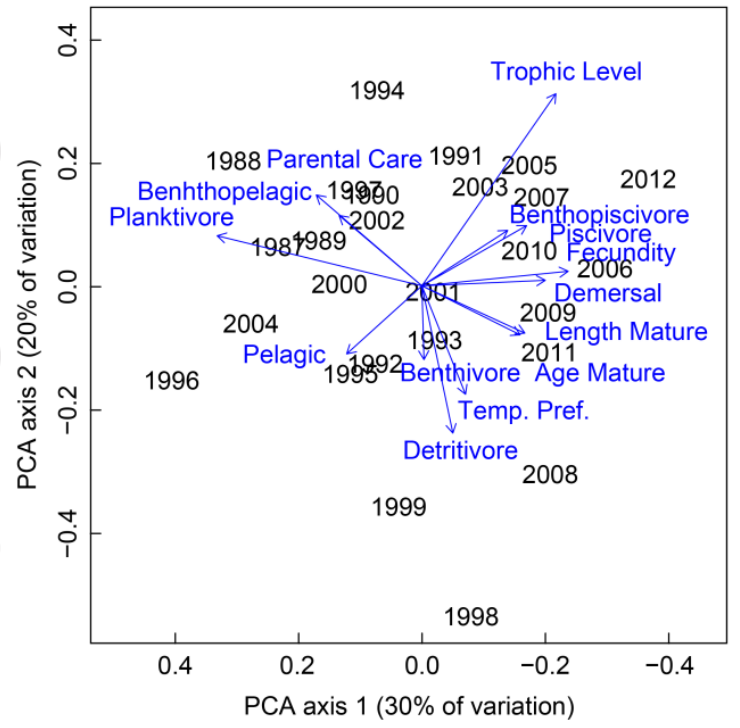

(c)

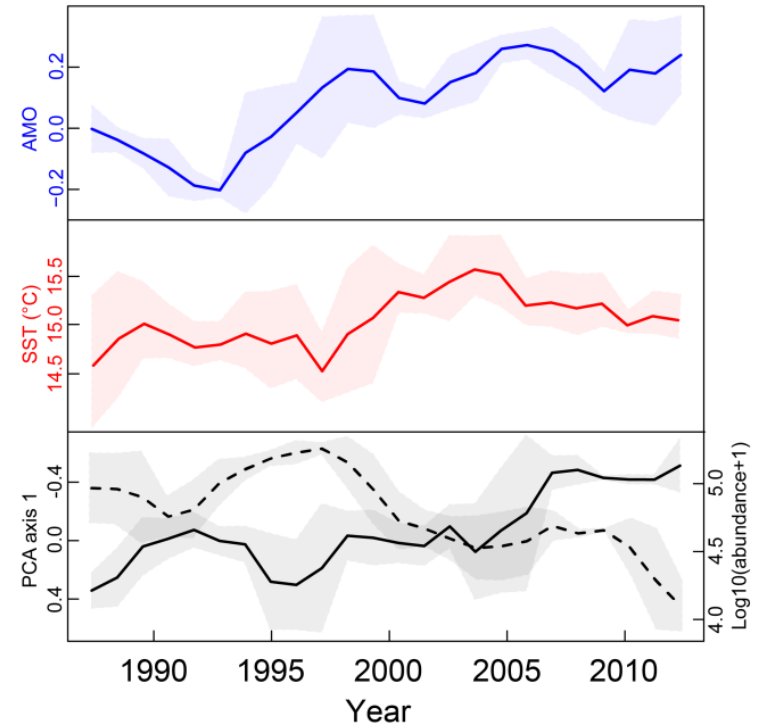

Outer Bay

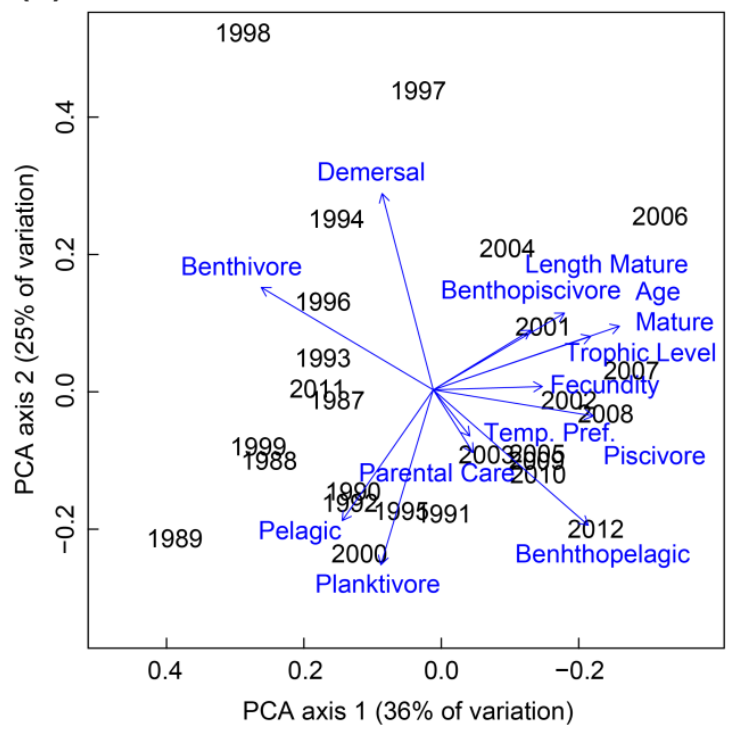

(d)

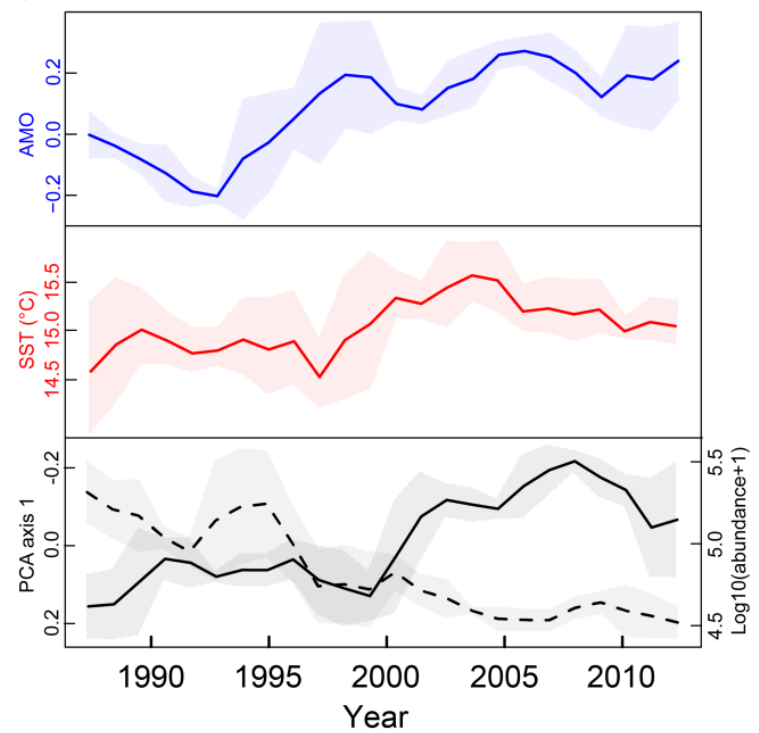

This article is protected by copyright. All rights reserved. 
Spatial Environmental Drivers

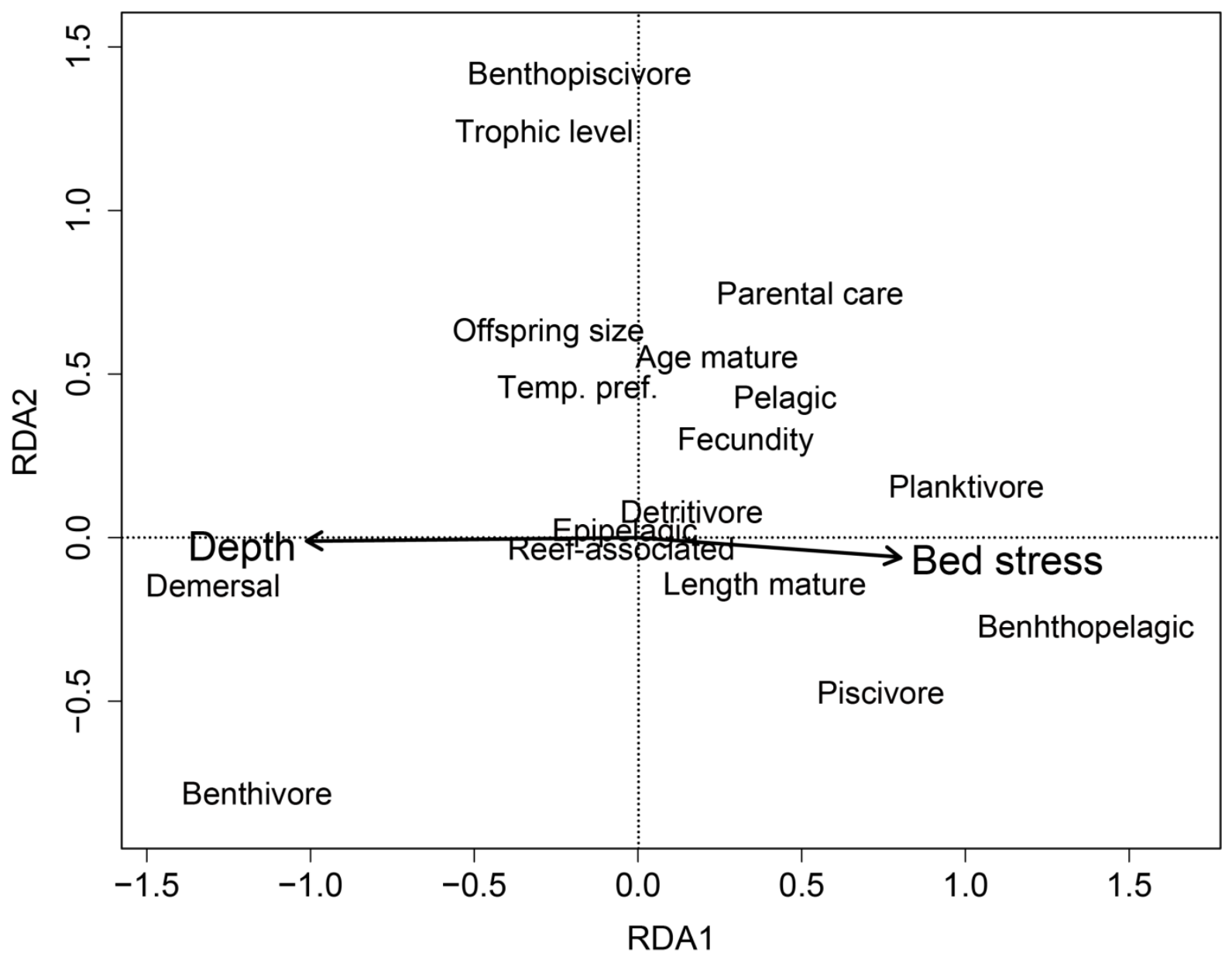

This article is protected by copyright. All rights reserved. 